\title{
Isolation and characterization of novel lectins from Canavalia ensiformis DC and Dioclea grandiflora Mart. ex Benth. seeds
}

\author{
Luz Marina Melgarejo ${ }^{1,2}$, Nohora Vega ${ }^{1}$ and Gerardo Pérez ${ }^{1, *}$
}

${ }^{1}$ Biochemistry Laboratory, Chemistry Department, Universidad Nacional de Colombia; 2 present address: Plant Physiology Laboratory, Biology Department, Universidad Nacional, Bogotá, Colombia; *Corresponding author: jrperezg@unal.edu.co

Received: 19/07/2005, Accepted: 03/10/2005

Two lectins were isolated from Canavalia ensiformis and Dioclea grandiflora seeds. Gel filtration produced a fraction corresponding to Con A or D. grandiflora lectin while erythroagglutination assays revealed a distinct fraction presenting a lectin that agglutinates human red blood cells (RBCs) but not rabbit RBCs. Hydrophobic interaction chromatography showed that the latter fraction yielded a protein that readily agglutinates human erythrocytes; the lectin was also purified by affinity chromatography on Lac-Sepharose showing similar properties to that of the Phenyl-Sepharose-purified lectin. Despite minor differences (carbohydrate content or $\mathrm{A}^{1 \%}{ }_{1 \mathrm{~cm}}$ ), the two lectins showed similar molecular properties in that they consisted of two non-covalently linked monomers having a $M_{r}$ of $29-30 \mathrm{kDa}$ and their $\mathrm{pI}$ values indicated that both lectins were slightly acidic proteins. The C. ensiformis lectin (CEL-II) and D. grandiflora lectin (DGL-II) specifically recognised the H-type 2 blood group ( $\alpha$-L-Fuc (1-2)- $\beta$-D-Gal (1-4)- $\beta$-D-GlcNAc-O-R), while binding to H-type 1, H-type 3, H-type 4 , Le $^{\mathrm{a}}$ or Le ${ }^{\mathrm{y}}$ was weaker. Carbohydrate inhibition of erythroagglutination showed that simple sugars were weakly recognised by the lectins, if at all. The $\mathrm{N}$-terminal region presented a unique sequence hitherto found only in some Diocleinae lectins (designated type II). The overall results confirmed the existence of a second distinct lectin type, phylogenetically close to Diocleinae species. The data indicate a functional similarity among lectins of this type which possesses distinctive characteristics differentiating them from "classical" Man/Glc lectins.

Key words: Diocleinae, Leguminoseae, characterization, lectins.

Isolamento e caracterização de novas lectinas de sementes de Canavalia ensiformis DC e Dioclea grandiflora Mart. ex Benth.: Isolaram-se lectinas de sementes de Canavalia ensiformis e Dioclea grandiflora. Coluna de filtração em gel produziu uma fração correspondente Con A ou lectina de D. grandiflora, enquanto ensaios de eritroaglutinação revelaram uma fração distinta, com uma lectina que aglutinou glóbulos vermelhos humanos, mas não de coelho. Cromatografia de interação hidrofóbica mostrou que a fração contendo a última lectina rendeu uma proteína que prontamente aglutinou eritrócitos humanos. Essa lectina também foi purificada por cromatografia de afinidade em coluna Lac-Sepharose e mostrou propriedades similares àquela purificada da coluna de interação hidrofóbica. Apesar de pequenas diferenças (conteúdo de carboidratos ou $\mathrm{A}^{1 \%}{ }_{1 \mathrm{~cm}}$ ), ambas lectinas mostraram propriedades moleculares semelhantes, consistindo em dois monômeros não-covalentemente ligados, com $M_{r}$ de 29-30 kDa, e com valores de $\mathrm{pI}$ que as indicavam como proteínas pouco acídicas. As lectinas de C. ensiformis (CELII) e D. grandiflora (DGL-II) reconheceram especificamente o grupo sanguíneo "H-type 2” ( $\alpha$-L-Fuc (1-2)- $\beta$-D-Gal (1-4)- $\beta$-DGlcNAc-O-R), com ligação mais fraca com os grupos "H-type 1, H-type 3, H-type 4, Lea ou Ley. Inibição de eritroaglutinação por carboidratos mostrou que açúcares simples foram fracamente reconhecidos pelas lectinas. A região N-terminal apresentou um seqüência única observada apenas em algumas lectinas de Diocleinae (denominadas tipo II). Os resultados confirmam a existência de um segundo tipo distinto de lectina, filogeneticamente próxima a espécies de Diocleinae. Os dados indicam uma similaridade funcional entre as lectinas desse tipo, que possuem características que as distinguem das clássicas lectinas Man/Glc.

Palavras chave: Diocleinae, Leguminoseae, caracterização, lectinas. 


\section{INTRODUCTION}

The specific carbohydrate recognition properties of lectins makes them important tools in glycobiology and, although their physiological role still remains unknown, they appear to mediate protein-cell and cell-cell interactions (Sharon and Lis, 1989).

The vast majority of lectins have been isolated from Leguminosae, although they are also present in bacterial and animal cells (Liener et al., 1986). ConA is the most extensively studied lectin, being present in Canavalia ensiformis, a species from the Diocleinae subtribe. This subtribe is widely distributed throughout the neotropics and, in recent years, several species from the genus Dioclea have been shown to possess a lectin closely related to ConA. The better characterized lectins are those from $D$. grandiflora (Moreira et al., 1983, Richardson et al., 1984), D. lehmanni Diels (Pérez et al., 1990, Pérez et al., 1991), D. sericea Kunth (Sierra and Pérez, 1999) and D. altissima Rock (Moreira et al., 1997) seeds. Lectins from Cratylia molllis Mart. ex Benth. (Correia and Coelho, 1995), D. virgata (Rich) Amshoff (Sousa Cavada et al., 1996a), D. rostrata Benth. (Sousa Cavada et al., 1996b) and D. violacea Mart. ex Benth. (Moreira et al., 1996) seeds have been partially characterized. All of them belong to the Man/Glc group and have very similar physicochemical properties and structural features.

Pérez (1998) has shown that a second lectin is present in the seeds of D. lehmanni (DLL-II), having distinct structural and functional properties. It is localised in mature cotyledon protein bodies where the lectin analogous to ConA (DLLI) is also present (Melgarejo and Pérez, 1997). The aim of the present investigation was to determine the presence and properties of lectins similar to DLL-II in the related $C$. ensiformis and D. grandiflora species.

\section{MATERIAL AND METHODS}

Materials: C. ensiformis seeds were collected near San Juan de Arama, Meta (Colombia), and D. grandiflora seeds were collected in Crato, Ceará (Brazil) and kindly provided by Dr R. Moreira (Universidade Federal do Ceará, Brazil). Fresh human blood was obtained from the University's clinical laboratory. Animal erythrocytes were supplied by the Veterinary Faculty's haematology laboratory. Pharmacia and BioRad supplied the chromatographic supports. ConASepharose and proteins were all obtained from Sigma. The neoglycoconjugates were a kind gift from Dr J. Le Pendu (INSERM, Nantes). Sugars and commercial products were of the highest available purity. The reagents for sequence determination were all sequencer grade. The rest of the reagents were analytical grade.

Lectin purification: Defatted flour of C. ensiformis or D. grandiflora seeds (10 $\mathrm{g}$ in small-scale experiments and 150$200 \mathrm{~g}$ in medium-scale experiments) was extracted $(1: 10, \mathrm{w} / \mathrm{v})$ with $1 \% \mathrm{NaCl}, 5 \mathrm{mM}$ PMSF, $2.5 \mathrm{mM}$ EDTA, $2.5 \mathrm{mM}$ EGTA and $0.4 \mu \mathrm{M}$ Leupeptin at $\mathrm{pH}$ 7.0. The procedure followed was essentially as that described by Peña et al. (1988), using three consecutive extractions. The extracts were pooled and precipitated overnight at $4^{\circ} \mathrm{C}$ with ammonium sulphate 30-70 $\%$ saturation for D. grandiflora and 50-70\% saturation for $C$. ensiformis. After centrifugation at $39,000 g_{n}$ for $20 \mathrm{~min}$ at $4^{\circ} \mathrm{C}$, the pellet was suspended in water and dialysed (x3) against $50 \mathrm{mM}$ ammonium bicarbonate $\mathrm{pH} 8$ and freeze-dried. The freeze-dried material $(0.4 \mathrm{~g})$ was fractionated on Sephacryl S$200(2.5 \times 148 \mathrm{~cm})$ using the same procedure as described for the D. lehmanni lectin (DLL-II) (Pérez, 1998). Three fractions (I-III) were obtained after Sephacryl S-200 chromatography of which II and III exhibited erythroagglutination. These fractions were dialysed and freeze-dried as described above. The freeze-dried fraction II $(40-50 \mathrm{mg})$ were applied to a Phenyl-Sepharose 4B column equilibrated with $20 \mathrm{mM}$ phosphate buffer $\mathrm{pH} 7.2$ containing $150 \mathrm{mM} \mathrm{NaCl}$ (PBS) and eluted by a $0-50 \%$ linear acetonitrile $(\mathrm{MeCN})$ gradient. In some instances, the $\mathrm{MeCN}$ gradient was replaced by elution with deionised $\mathrm{H}_{2} \mathrm{O}$. Alternatively, a Lac-Sepharose support was used as affinity matrix, according to Almanza et al. (2004). A crude extract or fraction II from Sephacryl S-200 was applied to the support and the lectin eluted with $0.2 \mathrm{M}$ Lac-PBS, dialysed and freeze-dried as described above.

General methods: The methods cited by Pérez (1984) were used for determining agglutination and carbohydrate inhibition as well as for protein, neutral sugars, Trp content and extinction coefficients. The specific titre was defined as being the haemagglutination titre divided by the protein concentration $\left(\mathrm{mg} \cdot \mathrm{mL}^{-1}\right)$ of the assay solution. This assay was carried out with $\mathrm{O}+$ erythrocytes. Amino acid composition was determined using an Applied Biosystems 421 Amino Acid Analyzer. The minimal inhibitory concentration assays were carried out with 30-150 mM lactose, melezitose and sucrose with $25 \mu \mathrm{L}$ pure lectin and $\mathrm{A}^{+}$erythrocytes. SDSPAGE was performed using a $15 \%$ separating gel and 4 $\%$ stacking gel, according to Laemmli (1970). The lectin's glycoprotein nature was assessed using the periodate-Schiff and ConA-peroxidase (Faye and Chrispeels, 1985) methods. 
Lectin binding to neoglycoconjugates: The assay method was similar to that described by Almanza et al. (2004). The neoglycoconjugates $(100 \mu \mathrm{L})$, diluted to 0.68 $\mu \mathrm{g} . \mathrm{mL}^{-1}$, were coated on microtitration plates (NUNC, F16 Maxisorp) by incubating for $3 \mathrm{~h}$ at $37^{\circ} \mathrm{C}$ and then overnight at room temperature. Each plate was then washed once with PBS-20\% Tween and twice with PBS. After blocking the free sites with $200 \mu \mathrm{L} 3 \% \mathrm{BSA}-\mathrm{PBS}$ for $1 \mathrm{~h}$ at $37^{\circ} \mathrm{C}, 100$ $\mu \mathrm{L}$ biotinylated lectin $\left(0.5 \mathrm{mg} \cdot \mathrm{mL}^{-1}\right)$ were added serially diluted in $3 \%$ BSA-PBS and incubated for $2 \mathrm{~h}$ at $37^{\circ} \mathrm{C}$. Each plate was then washed once with PBS-20\% Tween and twice with PBS. Streptavidin-peroxidase $(100 \mu \mathrm{L}$ at 1 mg.mL $\mathrm{mL}^{-1}$, diluted $1: 500$ in $3 \%$ BSA-PBS) was added and incubated for $1 \mathrm{~h}$ at $37^{\circ} \mathrm{C} . \mathrm{H}_{2} \mathrm{O}_{2}-2,2^{\prime}$-azino-bis (3ethylbenzothiazoline-6-sulfonic acid (ABTS) was added after five washes (the first one with PBS-20\% Tween and the rest with PBS) and $\mathrm{Abs}_{405}$ was read in a Bio-Rad ELISA autoreader.

Molecular weight: Native protein $M_{r}$ was determined using a Biogel P150 column $(1.5 \times 110 \mathrm{~cm})$ equilibrated with 10 $\mathrm{mM}$ phosphate buffer $\mathrm{pH}$ 7.4. BSA (66.2 kDa), $\alpha$-amylase (50 kDa), ovalbumin (45.0 kDa), myoglobin (17.2 kDa) and lysozyme $(14.3 \mathrm{kDa})$ were used as standards. Subunit Mr was determined by SDS-PAGE, according to Laemmli (1970); the protein standards were the same as above.

$p I$ : The $\mathrm{pI}$ was determined in non-denaturing conditions, according to Bollag and Edelstein (1991), using a 3.5-10 pH gradient.

$N$-terminal amino acid sequence: The protein was subjected to SDS-PAGE followed by Western blot transfer to a PVDF membrane (Matsudaira, 1987). The protein band was cut out and its sequence determined with an Applied Biosystems 470A Protein Sequencer (18 cycles).

Protease V8 digestion: The protein was digested according to Cleveland et al. (1977) and the peptide digest was subjected to electrophoresis according to Schagger and von Jagow (1987). The resulting bands were transferred to a PVDF membrane (Matsudaira, 1987) and sequenced with an Applied Biosystems 470A Protein Sequencer.

\section{RESULTS}

Lectin purification: Fractionation of $C$. ensiformis extracts by Sephacryl S-200 (figure 1A) yielded three fractions.
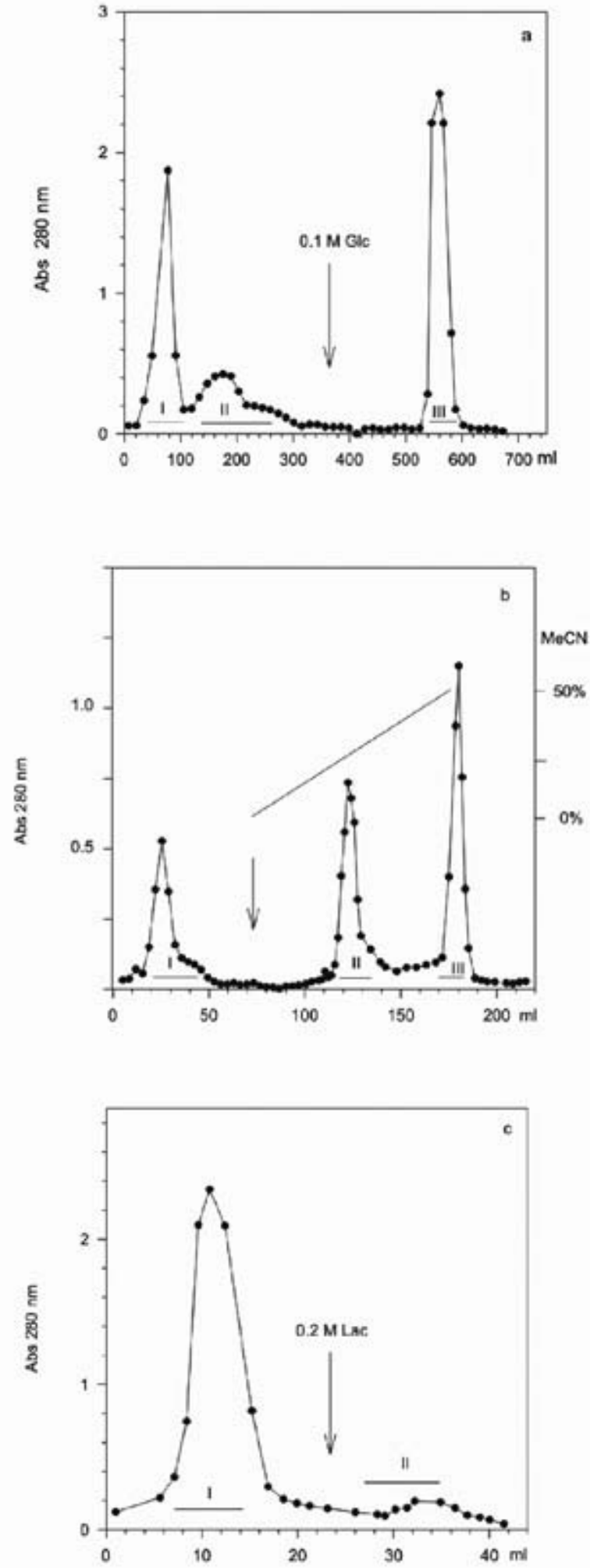

Figure 1. Canavalia ensiformis type-II lectin purification. (a) Gel filtration of $\left(\mathrm{NH}_{4}\right)_{2} \mathrm{SO}_{4} 50-70 \%$ saturation precipitate on Sephacryl S-200. (b) Hydrophobic chromatography of fraction II (eluted from Sephacryl S-200) on PhenylSepharose 4B. (c) Affinity chromatography of crude extract on Lac-Sepharose 4 B. 
Fraction III corresponded to Con A since it showed the same erythroagglutination characteristics (rabbit positive, human negative), carbohydrate inhibition pattern and dextran gel-binding properties as those shown by Con A (Agrawal and Goldstein, 1967; Olson and Liener, 1967). Erythroagglutination assays of fraction II revealed the presence of a lectin that agglutinated human red blood cells (RBCs) but not rabbit RBCs. This fact explains why this lectin has been hitherto undetected in C. ensiformis extracts as current procedures only employ rabbit RBCs. Similar behaviour has been observed by Pérez (1998) and Sierra and Pérez (1999) with D. lehmanni and D. sericea type-II lectins. Fraction II was therefore chromatographed on a Phenyl-Sepharose column and a MeCN gradient used to elute the retained fraction. The elution profile (figure 1B) showed three peaks, of which only II was able to agglutinate human erythrocytes; the third peak (devoid of erythroagglutination activity and characteristically turbid) was eluted at the very end of the gradient; $\mathrm{MeCN}$ was occasionally and advantageously replaced by deionised $\mathrm{H}_{2} \mathrm{O}$ with similar results, the only difference being the smaller size of the eluted peaks (results not shown). The $\mathrm{H}_{2} \mathrm{O}$-eluted protein was able to agglutinate human RBCs and preliminary experiments (SDS-PAGE, carbohydrate inhibition of erythroagglutination) showed that it possessed the same properties as the MeCN-eluted protein. Protein elution by $\mathrm{H}_{2} \mathrm{O}$ probably occurred due to the weakening of hydrophobic interactions between the lectin and the support; a similar situation has been described during the purification of Phaseolus (Ochoa and Kristiansen, 1978) and Arthocarpus lectins (Moreira and Oliveira, 1983).
An alternative way of purifying the lectin is suggested by the similarity between Galactia lindenii lectin and Dioclea lectins observed by Almanza et al. (2004). As the former was usually purified by affinity chromatography on Lac-Sepharose, crude extracts from C. ensiformis or fractions II from Sephacryl S-200 were run on this support. The elution profile showed a distinct fraction eluted by $0.2 \mathrm{M}$ Lac-PBS (figure $1 \mathrm{C}$, fraction II) which presented similar behaviour to the Phenyl-Sepharose purified lectin after dialysis. Most characterization assays were done on the latter. Quantifying lectin activity during the several purification steps showed that the specific C. ensiformis lectin II (CEL-II) titre increased as its purification proceeded (table 1). The purification achieved after the hydrophobic chromatography step was 25.7 fold, which was higher than that obtained with DLL-II (9.6 fold) (Pérez, 1998).

Similar results were obtained with $D$. grandiflora extracts which yielded a fraction (figure 2A, fraction II) after Sephacryl S-200 chromatography that was able to agglutinate human RBCs and a fraction eluted by $0.2 \mathrm{M}$ Glc (figure 2A, fraction III) which was unable to agglutinate human RBCs and corresponded to the DGL-I lectin described from $D$. grandiflora (Moreira et al., 1983). An erythroagglutinating peak (figure 2B, fraction II), named DGL-II, eluted with the MeCN gradient when fraction II was run on PhenylSepharose, while elution with $\mathrm{H}_{2} \mathrm{O}$ yielded a similar profile (results not shown) with an erythroagglutinating protein fraction II. Affinity chromatography on Lac-Sepharose allowed the lectin to be recovered (figure $2 \mathrm{C}$, fraction II). PAGE-SDS of CEL-II and DGL-II revealed a single $M_{r}$ 29-30 kDa band (figure 3). Protein amount and specific titre were monitored throughout the several purification steps (table 2), where a 33.5 fold purification was achieved.

Table 1. Purification of lectin II from C. ensiformis.

\begin{tabular}{|c|c|c|c|c|c|}
\hline Purification step & Volume (mL) & Protein $\left(\mathrm{mg} \cdot \mathrm{mL}^{-1}\right)$ & Total Protein (mg) & Specific Titre ${ }^{a}$ & Purification (fold) \\
\hline 1. First saline extract & 83 & 17.69 & 1468.3 & 0.45 & \\
\hline 2. Second saline extract & 96 & 7.26 & 967 & 0.28 & \\
\hline 3.Third saline extract & 103 & 1.73 & 178.2 & 0.58 & \\
\hline Pooled saline extracts & 282 & 7.56 & 2131.9 & 1.06 & 1.0 \\
\hline 4. $50-70 \%\left(\mathrm{NH}_{4}\right)_{2} \mathrm{SO}_{4}$ & 29 & 9.75 & 282.8 & 1.64 & 1.55 \\
\hline 5. Affinity Chromatography Peak II b & 190 & 0.641 & 121.8 & 3.12 & 2.94 \\
\hline 6.Hydrophobic chromat c & 36 & 0.294 & 10.6 & 27.21 & 25.67 \\
\hline
\end{tabular}

${ }^{a}$ The specific titre is defined as the haemagglutination titre divided by the protein concentration $\left(\mathrm{mg} \cdot \mathrm{mL}^{-1}\right)$ of the assayed solution. This assay was done with $\mathrm{O}+$ erythrocytes; ${ }^{\mathrm{b}} 240.29 \mathrm{mg}$ of freeze-dried globulin fraction applied to the column; ${ }^{\mathrm{c}} 42.84 \mathrm{mg}$ of freeze-dried fraction II applied to the Phenyl-Sepharose column. 

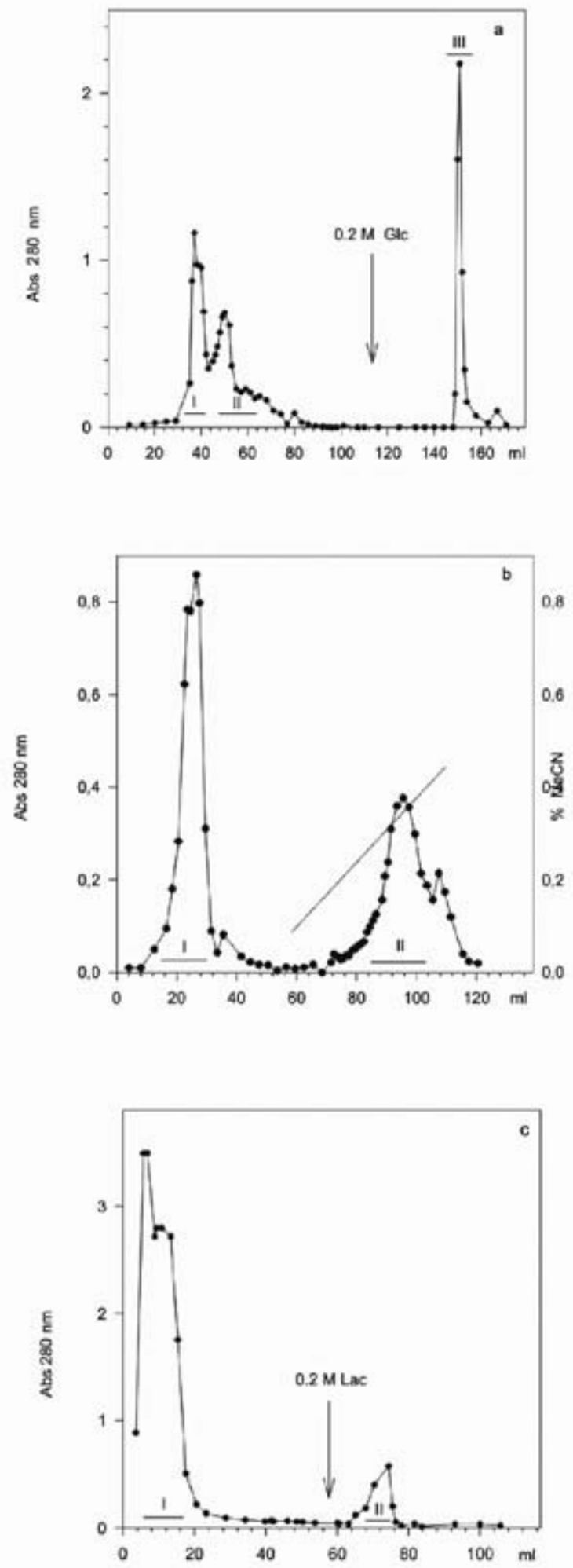

Figure 2. Dioclea grandiflora type-II lectin purification. (a) Gel filtration of $\left(\mathrm{NH}_{4}\right)_{2} \mathrm{SO}_{4} 30-70 \%$ saturation precipitate on Sephacryl S-200. (b) Hydrophobic chromatography of fraction II (eluted from Sephacryl S-200) on PhenylSepharose 4B. (c) Affinity chromatography of crude extract on Lac-Sepharose 4 B.

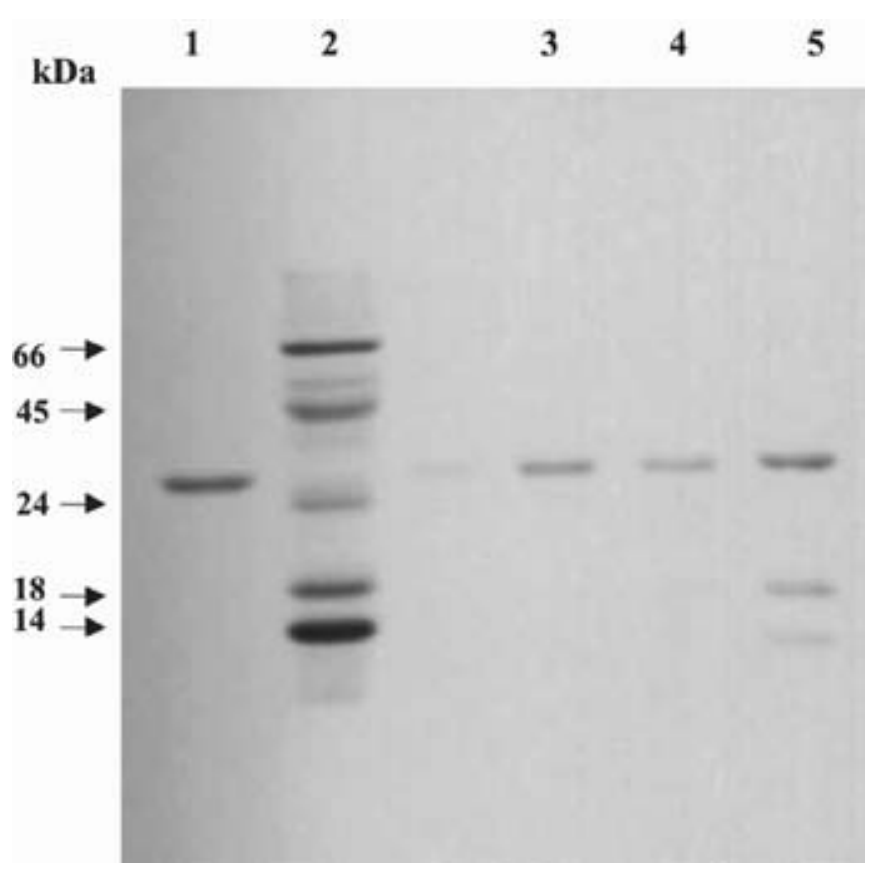

Figure 3. SDS-PAGE of CEL-II and DGL-II. Lane 1, DGL-II; lane 2, molecular weight standards; lane 3, CEL-II ; lane 4, DLL-II; lane 5, Dioclea grandiflora lectin (I).

Erythroagglutination and carbohydrate inhibition: Human $\mathrm{A}+, \mathrm{A}_{1}+, \mathrm{B}+$ or $0+\mathrm{RBC}$ were agglutinated to the same extent by CEL-II and DGL-II, presenting distinct behaviour to that of ConA (C. ensiformis type I lectin) or DGL, which characteristically agglutinate rabbit erythrocytes with higher specific titres than those shown for human RBCs (Pérez, 1998).

Amongst the tested carbohydrates (c.a. 30), CEL-II and DGL-II were only inhibited by di/trisaccharides having no apparent structural relationship, contrary to that established for ConA and DGL-I which recognise Glc/Man (table 3). Although weak, melezitose inhibition was clearly stronger for DGL-II than for DLL-II. The relatively high sugar concentrations needed to inhibit erythroagglutination indicates that type II lectins probably recognise more complex structures.

Lectin binding to neoglycoconjugates: CEL-II bound the Htype 2-BSA neoglycoconjugate 10 times more strongly than H-type 1 and about 100 times more strongly than H-type 3 or $\mathrm{H}$-type 4 (figure 4A) in our experimental conditions. Binding to $\mathrm{Le}^{\mathrm{a}}$ and $\mathrm{Le}^{\mathrm{y}}$ was equally weak. DGL-II behaved similarly to CEL-II, showing stronger binding to H-type 2-BSA than to the other assayed neoglycoconjugates (figure 4B). H-type 2 binding specificity was also observed with $D$. lehmanni lectin-II (figure 4C). 
Table 2. Purification of lectin II from D. grandiflora

\begin{tabular}{|c|c|c|c|c|c|}
\hline Purification step & Volume (ml) & Protein $\left(\mathrm{mg} \cdot \mathrm{mL}^{-1}\right)$ & Total Protein $(\mathrm{mg}))$ & Specific Titre $^{\mathrm{a}}$ & Purification (fold) \\
\hline 1.First saline extract & 90 & 24.28 & 2185.20 & 2.64 & \\
\hline 2. Second saline extract & 95 & 5.79 & 550.1 & 0.69 & \\
\hline 3. Third saline extract & 94 & 1.64 & 154.2 & 0.61 & \\
\hline Pooled saline extracts & 279 & 10.32 & 2879.3 & 0.78 & 1.0 \\
\hline 4. $30-70 \%\left(\mathrm{NH}_{4}\right)_{2} \mathrm{SO}_{4}$ & 30 & 21.56 & 646.8 & 2.97 & 3.81 \\
\hline 5.Affinity Chromatography Peak II b & 125 & 0.609 & 76.13 & 3.28 & 4.21 \\
\hline 6.Hydrophobic chromat. ${ }^{c}$ & 14 & 0.612 & 8.57 & 26.14 & 33.51 \\
\hline
\end{tabular}

a The specific titre is defined as the haemagglutination titre divided by the protein concentration (mg.mL ${ }^{-1}$ ) of the assayed solution. This assay was done with $\mathrm{O}+$ erythrocytes; b $292 \mathrm{mg}$ of freeze-dried globulin fraction applied to the column; ${ }^{\mathrm{c}} 39.87 \mathrm{mg}$ of freeze-dried fraction II applied to the column.

Table 3. Erythroagglutination inhibition by carbohydrate of DGL-II and CEL-II

\begin{tabular}{lccc}
\hline Sugar $(\mathrm{mM})$ & DGL-II & CEL-II & DLL-II $^{\mathrm{a}}$ \\
\hline Lactose & 90 & 75 & 92 \\
Melezitose & 25 & 50 & 100 \\
Saccharose & 40 & 40 & 112 \\
D - Mannose & $-\mathrm{b}$ & $-\mathrm{b}$ & $-\mathrm{b}$ \\
D - Glucose & - b & $-\mathrm{b}$ & $-\mathrm{b}$ \\
\hline
\end{tabular}

a Data taken from Pérez (1998); b 200 mM.

Molecular properties: The lectin subunit molecular weight (determined by SDS-PAGE) was close to $29-30 \mathrm{kDa}$ (figure 3 ), being practically the same as that presented by DLL-II and DSL-II (table 4). The electrophoretic pattern was clearly different from that exhibited by type-I lectins where three polypeptide chains $(\alpha=29-30 \mathrm{kDa}, \beta=16-17 \mathrm{kDa}$ and $\gamma=$ $12-13 \mathrm{kDa}$ ) are always present and arise as products from post-transcriptional processing of the mature chain (Bowles et al., 1986). Gel filtration revealed that the two lectins had similar molecular weights in their native state, being close to those shown by DLL-II and DSL-II (Table 4). Taking subunit MW into account, it is likely that the lectins were in dimeric form. It has been demonstrated (Moreira et al., 1983; Goldstein and Poretz, 1986) that tetrameric forms prevail in type I lectins, which are in rapid equilibrium with dimers and monomers whose amount depends on $\mathrm{pH}$ or solution ionic strength.

Determination of the pI showed that DGL-II and CEL-II were slightly acidic proteins (table 4) whereas ConA and DGL-I were neutral or clearly basic proteins. The several close bands observed (results not shown) were most likely due to isoforms which also appeared to be present in DSL-II.
As opposed to type I lectins, CEL-II and DGL-II revealed the presence of associated carbohydrate which was also present in previously analysed type II Diocleinae lectins (table 4).

Amino acid composition: Table 5 shows the amino acid composition of the two lectins. DGL-II showed high amounts of acidic and hydroxy amino acids as well as Gly and Ala; sulphur amino acids were very scarce. A similar amino acid distribution was found for CEL-II, while DLLII and DSL-II are shown for comparison. The extinction coefficient values found for the type-II lectins (table 4) were similar to those expected from their Trp and Tyr content.

The calculated $M_{r}$ of CEL-II $(24,311)$ on the basis of amino acid composition was close to the $M_{r}$ calculated from SDSPAGE data, taking the carbohydrate content into account $(28,626)$. In the case of DGL-II, calculations showed similar agreement $(24,393$ of 28,391). The resulting differences in both cases can be accounted for by the well-established $M_{r}$ deviations exhibited by glycoproteins when analysed by electrophoresis. $M_{r}$ over-estimation was evidenced by comparing the value determined for DSL-II by SDS-PAGE to that obtained by MALDI-TOF MS (table 4).

$N$-terminal sequence: DGL-II and CEL-II N-terminal sequences are shown in table 6. DLL-II, DSL-II, GLL, Con A and DGL-I N-terminal sequences are included for comparison. All residues could not be determined due to the limited amount of CEL-II. However, the available information allowed us to align its sequence with that of DGL-II and those of other lectins. The DGL-II N-terminal sequence showed a very high similarity to DLL-II, as only 6 out of 49 residues were not identical, including a two-residue gap and the substitution at position 29 (NxD). 

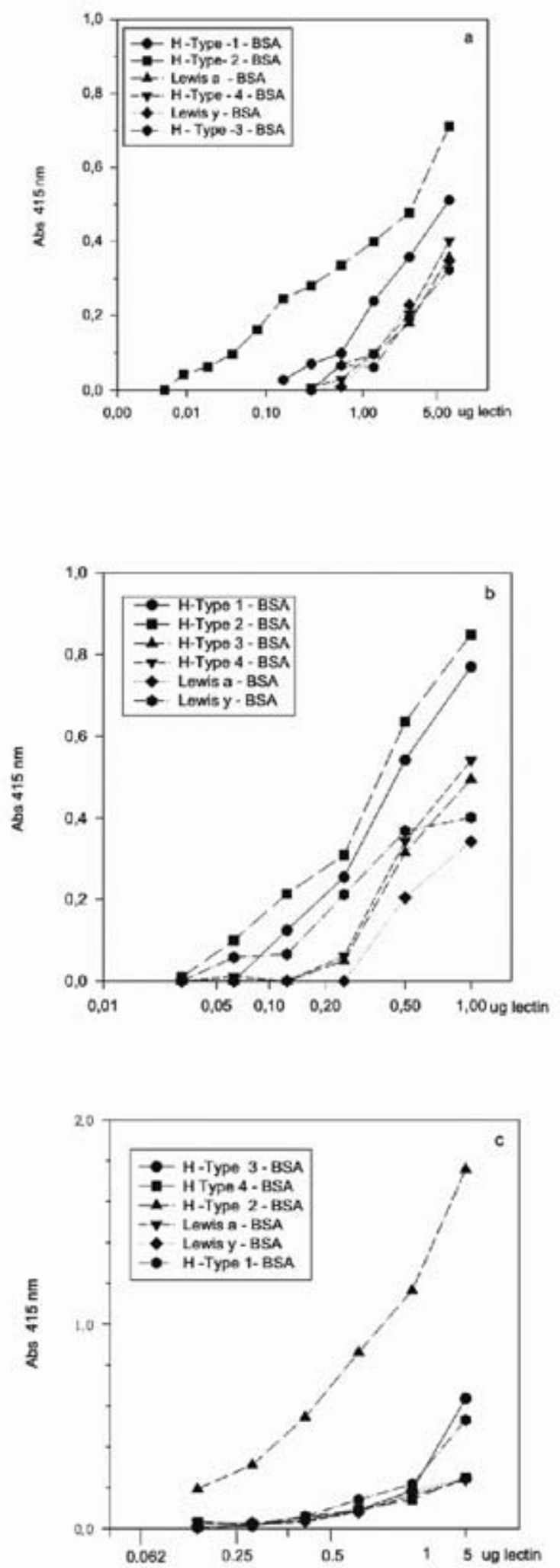

Figure 4. Lectin binding to H-type neoglycoconjugates. (a) Canavalia ensiformis type-II lectin. (b) Dioclea grandiflora type-II lectin. (c) Dioclea lehmanni type-II lectin.
Taking the CEL-II determined residues into account (21), all were identical to corresponding positions in DGL-II and a remarkable similarity was observed with the hitherto described Dioclea type-II lectins. It is likely that the seven undetermined residues (X) were similar to those of DGL-II. It is noteworthy that the SSSS sequence was present in all type II lectins from the Dioclea genus as well as in G. lindenii lectin. DGL-II and CEL-II N-terminal sequences were clearly different from those of Con A and DGL-I lectins.

DGL-II digestion with protease V8 yielded (amongst recovered peptides) +GAVYF, VSNNGILALT and FDDYSN $+\mathrm{W}++\mathrm{P}$ peptides. The first one probably corresponds to the N-terminal end; the second peptide (residues 26-35) confirmed the NGILA sequence which appeared to be present only in DGL-II. The third peptide was homologous to D. lehmanni type-II lectin residues 124-130 (Pérez, unpublished results).

\section{DISCUSSION}

A close examination of Dioclea and Canavalia extract elution profiles on dextran supports (G-50/G-75), commonly employed for isolating Glc/Man specific lectins (Moreira et al., 1993, 1996, 1997; Correia and Coelho, 1995; Sousa Cavada et al., 1996a; 1996b), shows (in all cases) a distinct unretained second peak. Type-II lectins are characteristically present in this fraction and have probably been overlooked as no erythroagglutination assays have been carried out with human RBCs. It should be recalled that no agglutination of human RBCs has been observed with this lectin since ConA was isolated (Sumner and Howell, 1936).

An estimation of the amount of lectin recovered showed lower proportions of CEL-II and DGL-II than DLL-II, these being $1.84 \mathrm{mg} . \mathrm{g}^{-1}$ flour (Pérez, 1998) or GLL, $5.88 \mathrm{mg} . \mathrm{g}^{-1}$ flour (Almanza et al., 2004), suggesting different expression levels.

Despite minor differences (carbohydrate content or $\mathrm{A}^{1 \%}{ }_{1 \mathrm{~cm}}$ ) the two lectins showed similar molecular properties, i.e. non-covalently linked homodimers with $57-58 \mathrm{kDa} M_{r}$, 29-30 kDa $M_{r}$ subunit and a 5.1-5.4 pI.

The high similarity shown by the Diocleinae lectins in the N-terminal region prompted us to search for homology/ similarity with lectins from several Fabaceae and other nonleguminous plants; no similarity with any N-terminal lectin sequence was found, suggesting that, contrary to common belief, legume lectins have at least two distinctive N-terminal regions. The possibility that this region corresponds to a signal peptide was excluded as no similarity was found when lectin 
Table 4. Molecular properties of lectins from Diocleinae species

\begin{tabular}{|c|c|c|c|c|c|c|}
\hline & \multicolumn{2}{|c|}{ D. grandiflora } & \multicolumn{2}{|c|}{ C. ensiformis } & \multirow{2}{*}{$\frac{\text { D. lehmanni }}{\text { Lectin II }^{\mathrm{d}}}$} & \multirow{2}{*}{$\begin{array}{l}\text { D. sericea } \\
\text { Lectin }{ }^{\mathrm{e}}\end{array}$} \\
\hline & Lectin II. $^{\mathrm{a}}$ & Lectin $\mathrm{I}^{\mathrm{b}}$ & Lectin II. $^{\mathrm{a}}$ & Con $\mathrm{A}^{\mathrm{c}}$ & & \\
\hline$M_{r}(\mathrm{kDa})$ Native protein & 58.9 & 100 & 57.5 & $106^{\mathrm{f}}$ & 58.4 & $\begin{array}{l}53,273^{\mathrm{g}} \\
57.3^{-02}\end{array}$ \\
\hline$M_{r}(\mathrm{kDa})$ Subunits & $29-30$ & $\begin{array}{c}25-26 ; 13-14 ; 8-9 \\
86 \cdot 87 .\end{array}$ & $29-30$ & $26.5 ; 14.0 ; 12.5^{\mathrm{f}}$ & $29-30$ & $\begin{array}{l}26,582^{g} \\
30\end{array}$ \\
\hline pI & $5.4,5.3,5.1$ & $\begin{array}{c}8.6 ; 8.7 \\
8.8 ; 8.9 ; 9.0\end{array}$ & $5.4 ; 5.3 ; 5.2$ & 7.1 & 6.55 & $5.72,5.38$ \\
\hline Neutral sugars $(\%)$ & 2.1 & - & 1.3 & - & 4.1 & 1.5 \\
\hline $\mathrm{A}^{1 \%}{ }_{1 \mathrm{~cm}}$ & 21.8 & 12.0 & 17.8 & 11.4 & 23.95 & N.D. \\
\hline
\end{tabular}

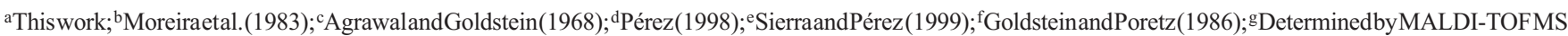

Table 5. Amino acid composition of DGL-II and CEL-II

D. grandiflora C. ensiformis D. lehmanni ${ }^{\text {a }}$ D. sericea ${ }^{\text {b }}$ Residues/mol Residues/mol Residues/mol Residues/mol

\begin{tabular}{lrrrr}
\hline Asx & 23 & 25 & 38 & 33 \\
Thr & 14 & 13 & 21 & 19 \\
Ser & 22 & 31 & 32 & 35 \\
Glx & 23 & 30 & 21 & 13 \\
Pro & 14 & 0 & 12 & 9 \\
Gly & 43 & 58 & 22 & 33 \\
Ala & 27 & 27 & 24 & 31 \\
Cys & 0 & 2 & $0^{\text {c }}$ & $0^{\text {c }}$ \\
Val & 16 & 15 & 25 & 22 \\
Met & 1 & 1 & $3^{\text {d }}$ & $3^{\text {d }}$ \\
Ile & 10 & 9 & 16 & 14 \\
Leu & 20 & 14 & 21 & 16 \\
Tyr & 4 & 4 & 9 & 7 \\
Phe & 7 & 5 & 9 & 9 \\
Lys & 9 & 7 & 13 & 9 \\
His & 4 & 4 & 1 & 2 \\
Arg & 6 & 5 & 8 & 4 \\
Trp & 2 & 3 & 4 & 6 \\
\hline
\end{tabular}

a Pérez (1998) ; b Sierra and Pérez (1999); c Determined as $\mathrm{CySO}_{3}$; Determined as $\mathrm{MetSO}_{2}{ }^{\text {e }}$ Determined spectrophotometrically. Calculations are based on a $M_{r} 29,000$ with $2.1 \%$ carbohydrate for $D$. grandiflora and 1.3 $\%$ carbohydrate for $C$. ensiformis lectins. precursor sequences were examined. The first eleven type-II lectin residues of Dioclea species are mainly hydrophobic amino acids, although this region has less marked hydrophobicity for the G. lindenii lectin. It is noteworthy that the SSSS sequence is present in all Dioclea genus typeII lectins as well as in G. lindenii lectin. We propose that this sequence is characteristic of type II Diocleinae lectins as it has not been found in any of the type-I lectins studied thus far.

Interestingly, Diocleinae type-II lectins (such as those found in the Galactia genus) specifically recognise and bind tightly to the $\mathrm{H}$ type-2 determinant (LePendu et al., 1986; Almanza et al., 2004). This fact, together with the structural relationships revealed by highly similar Nterminal regions, led us to test CEL-II and DGL-II binding to the $\mathrm{H}$ type-2 determinant. The relative order of binding to the neoglycoconjugates showed that the two lectins behaved similarly to $G$. lindenii lectin and D. lehmanni lectin.

Table 6. N-terminal sequence of D. grandiflora, C. ensiformis, D. lehmanni, D. sericea and G. lindenii lectins

\begin{tabular}{|c|c|c|c|c|}
\hline 10 & 20 & 30 & 40 & \\
\hline 1. A G A V Y F X F T K & F T T S S S S L T L & Q G S A E V S N N G & I L A L T N L K N P & T N K V G R A L Y \\
\hline 2. + GAV Y F + F T K & $\mathrm{F} \mathrm{T} \mathrm{T} \mathrm{S}+\mathrm{S}+\mathrm{L} \mathrm{T} \mathrm{L}$ & $+\mathrm{G}+\mathrm{AEV}+\mathrm{N}$ & & \\
\hline 3. A GA VYFYF T K & F T T S S S S L T L & Q G S A E V S N D H & K - - L T N L K N P & T N K V G R A L Y \\
\hline 4. A GA VYI R I TF & I T I S S S VLTL & & & \\
\hline 5. AKV T S I KY T S & I S - S S X G K P L & Q G N A & & \\
\hline 6. ADTIVA VELD & TY P N T D I G D P & D Y P H I G I D I K & S V R S K KT A KW & N M QD G K V G T \\
\hline 7. ADT I VA VELN & SY P N T D I G D P & N Y P H I G I D I K & S I R S K S T A RW & N M QT G K V G T \\
\hline
\end{tabular}

1. D. grandiflora lectin II; 2. C. ensiformis lectin II; 3. D. lehmanni lectin II (Pérez, 1998); 4. D. sericea lectin II (Sierra and Pérez, 1999) ; 5. G. lindenii lectin (Almanza et al., 2004); 6. C. ensiformis lectin (ConA) (Becker et al., 1975); 7. D. grandiflora lectin I (Richardson et al., 1984); X= unidentified residue. 
The overall results confirmed the existence of a second distinct lectin type in phylogenetically close Diocleinae species, as has been proposed by Almanza et al. (2004), and suggest a functional similarity amongst this type of lectin. These types of lectins possess distinctive characteristics that differentiate them from the "classical" Man/Glc lectins: a) Ability to strongly agglutinate human RBCs; b) specific interaction with Lac-Sepharose supports; c) recognition of H-type 2 trisaccharide; and d) $\mathrm{N}$ terminal sequences.

The evidence of a second different seed lectin in several Diocleinae species (including $C$. ensiformis and $D$. grandiflora) give rise to several questions. Are the two lectins localised in the same cellular compartment as occurs in $D$. lehmanni seeds (Melgarejo and Pérez, 1997)? Is there some sort of post-transcriptional processing as has been described for ConA (Herman et al., 1985; Bowles et al., 1986)? Is there a relationship between the expression levels of each lectin type? The still unresolved question concerning the physiological role of seed lectins seems to become more complex as distinct lectins occur simultaneously in a given species.

Acknowledgements: We wish to thank Dr J. LePendu (Nantes, INSERM) for his kind gift of neoglycoconjugates, Dr J.L. Fernández (ICN, Universidad Nacional) for species identification, Dr. L. Falquet (Swiss Institute of Bioinformatics) for his help and advice on multiple sequence alignments, Drs I. Hara-Nishimura and M. Nishimura (National Institute for Basic Biology, Japan) for the facilities provided to one of us (L.M.M.) and N-terminal sequence determinations. Financial support was provided by the Universidad Nacional's Chemistry Department and COLCIENCIAS.

\section{REFERENCES}

Agrawal BBL, Goldstein IJ (1967) Protein carbohydrate interaction. VI. Isolation of Concanavalin A by specific adsorption on cross-linked gels. Biochim. Biophys. Acta 147: 262-271.

Almanza M, Vega N, Pérez G (2004) Isolating and characterising a lectin from Galactia lindenii seeds that recognise blood group $\mathrm{H}$ determinants. Arch. Biochem. Biophys. 429: 180-190.

Becker JW, Reeke GN Jr, Wang JL, Cunningham BA, Edelman GM (1975) The covalent and three-dimensional structure of Concanavalin A. III. Structure of the monomer and its interactions with metals and saccharides. J. Biol. Chem. 250: 1513-1524.

Bollag DM, Edelstein S (1991) Protein Methods. Wiley-Liss, New York, USA.
Bowles DJ, Marcus SE, Pappin DJC, Findlay JBC, Eliopoulos E, Maycox PR, Burgess J (1986) Posttranslational processing of Concanavalin A precursors in jackbean cotyledons. J. Cell Biol. 102:1284-1297.

Cleveland DW, Fischer SG, Kirschner MW, Laemmli UK (1977) Peptide mapping by limited proteolysis in sodium dodecyl sulfate and analysis by gel electrophoresis. J. Biol Chem. 252:1102-1106.

Correia M, Coelho L (1995) Purification of a glucose/manose specific lectin, isoform 1, from seeds of Cratylia mollis Mart. (Camaratu Bean). Applied Biochem. Biotechnol. 55: 261-273.

Faye L, Chrispeels MJ (1985) Characterization of N-linked oligosaccharides by affinoblotting with concanavalin Aperoxidase and treatment of the blot with glycosidases. Anal. Biochem. 149:218-224.

Goldstein IJ, Poretz RD (1986) Isolation, physicochemical characterization and carbohydrate-binding specificity of lectins. In: Liener IE, Sharon N, Goldstein IJ (eds) The lectins, pp. 52. Academic Press, Orlando, USA.

Herman EM, Shannon LM, Chrispeels MJ (1985) Concanavalin A is synthesized as a glycoprotein precursor. Planta 165:23-29.

Laemmli UK (1970) Cleavage of structural proteins during the assembly of the head of bacteriophage T4. Nature 227: 680-685.

LePendu J, Gerard G, Lambert F, Mollicone R, Oriol R (1986) A new anti-H lectin from the seeds of Galactia tenuiflora. Glycoconjugate J. 3:203-216.

Liener IE, Sharon N, Goldstein IJ (1986) The lectins. Academic Press, Orlando, USA.

Matsudaira P (1987) Sequence from picomole quantities of proteins electroblotted onto polyvinyldiene difluoride membranes. J. Biol. Chem. 262:10035-10038.

Melgarejo LM, Pérez G (1997) Immunolocalization of the lectins P2 and P4 from Dioclea lehmanni seeds. Plant Cell Physiol. 38:480-483.

Moreira R, Barros AC, Stewart JC, Pusztai A (1983) Isolation and characterization of a lectin from the seeds of Dioclea grandiflora (Mart). Planta 158:63-69.

Moreira RA, Oliveira JTA (1983) Lectins from the genus Artocarpus. Biol. Plant. 25:343-348.

Moreira R, Cordeiro EF, Sousa-Cavada B, Nunes EP, Fernandes A, Oliveira JT (1993) Plant seed lectins. A possible marker for chemotaxonomy of the genus Canavalia. Rev. Bras. Fisiol. Veg. 5:127-132.

Moreira R, Cordeiro EF, Ramos M, Grangeiro TB, Maartins JL, Oliveira J, Sousa-Cavada B (1996) Isolation and partial characterization of a lectin from seeds of Dioclea violacea. Rev. Bras. Fisiol. Veg. 8:23-29.

Moreira R, Monteiro A, Oliveira J, Sousa-Cavada B (1997) Isolation and characterization of Dioclea altíssima var. megacarpa seed lectin. Phytochemistry 46:139-144.

Ochoa JL, Kristiansen T (1978) Stroma: As an affinity adsorbent for non-inhibitable lectins. FEBS Lett. 90:145-148.

Olson MOJ, Liener IE (1967) Some physical and chemical properties of Concanavalin A, the phytohemagglutinin of the jack bean. Biochemistry 6:105-111. 
Peña C, Villarraga F, Pérez G (1988) A lectin from the seeds of Erythrina rubrinervia. Phytochemistry 27:1045-1048.

Pérez G (1984) Purification and characterization of a lectin from the seeds of Erythrina edulis. Phytochemistry 23: 1229-1232.

Pérez G, Hernández M, Mora E (1990) Isolation and characterization of a lectin from the seeds of Dioclea lehmanni. Phytochemistry 29:1745-1749.

Pérez G, Pérez C, Sousa-Cavada B, Moreira R, Richardson M (1991) Comparison of the amino acid sequences of the lectins from seeds of Dioclea lehmanni and Canavalia maritima. Phytochemistry 30:2619-2621.

Pérez G (1998) Isolation and characterization of a novel lectin from Dioclea lehmanni (Fabaceae) seeds. Biochem. Cell Biol. 30:843-853.

Richardson M, Campos FD, Moreira RA, Ainouz LL, Begbie R, Watt WB, Pusztai A (1984) The complete amino acid sequence of the major $\alpha$ subunit of the lectin from the seeds of Dioclea grandiflora (Mart). Eur. J. Biochem. 144:101-111.
Schagger H, Von Jagow G (1987) Tricine-sodium dodecyl sulfate-polyacrylamide gel electrophoresis for the separation of proteins in the range from 1 to $100 \mathrm{kDa}$. Anal. Biochem. 166:368-379.

Sharon N, Lis H (1989) Lectins as cell recognition molecules. Science 240:227-234.

Sierra A, Pérez G (1999) Extracción, purificación y caracterización de dos lectinas en semillas de Dioclea sericea. Rev. Acad. Col. Ciencias 23:445-454.

Sousa-Cavada B, Ramos MV, Cordeiro EF, Grangeiro TV, Oliveira JTA, de Carvalho AF, Moreira RA (1996a) Purification and partial characterization of a lectin from Dioclea virgata Benth seeds. Rev. Bras. Fisiol. Veg. 8:37-42.

Sousa-Cavada B, Grangeiro TV, Ramos MV, Cordeiro EF, Oliveira JTA, Moreira RA (1996b) Isolation and partial characterization of a lectin from Dioclea rostrata Benth seeds. Rev. Bras. Fisiol. Veg. 8:31-36.

Sumner JB, Howell SF (1936) The identification of the hemagglutinin of the jack bean with concanavalin A. J. Bacteriol. 32:227-237. 